\title{
The Practice of Cultural History in Britain
}

LUDMILLA JORDANOVA

\section{Introduction}

It is widely acknowledged that cultural history is difficult to define. In the English language, the word culture presents some distinctive difficulties connected with the nature of classes and elites. So the history of that word, which is peculiarly complex, sits uneasily behind any attempt to speak about the characteristics of cultural history. What is also sitting there, equally uneasily, is the general history of the country in question. My task is to say something about cultural history in Britain: since historical practice is shaped by so many factors, such as resources, the structure and funding of higher education, attitudes to the past and national preoccupations, the history of Britain is necessarily relevant. However, cultural history produced in Britain or by British scholars is not necessarily about Britain. It is true that, as in most countries, our national history dominates both research and teaching. Nonetheless, some of our most influential cultural historians have not written about British history. My interest here concerns the ways in which historians working in Britain have practiced.

Immediately, however, it is necessary to issue a health warning. I argue that it is hard to identify national traditions in cultural history that are specifically Brit$i s h$. This is partly because the field has been so little institutionalized. The key area, I suggest, is rather social history. My experience is that historians are eclectic, piecing together bits and pieces when it comes to sources, perspectives, approaches and theories. I find it hard to identify schools of history, in the way that the Annales were deemed to have produced annalistes. The closest perhaps is the impact of Quentin Skinner's approach to the history of political thought. It could be argued that culture has played its part in a style of history that is so closely associated with Cambridge. But on the whole when we use the phrase cultural history that is not what springs to mind. So what we have, I will suggest, is a great 
deal of cultural history, which is heterogeneous. It would not be useful to provide simple lists of people, projects and places, for example, hence I have approached the huge challenge in a different manner. First, I consider what the problems are with defining cultural history. Then I pursue further some of the themes that arose in the process and especially the relationships between social and cultural history. The final section adopts a different, autobiographical vantage point.

\section{Defining Cultural History}

It seems to me that there are three broad approaches we can take in defining cultural history. First, it is possible to say simply that just as political history is the history of politics, so cultural history is the history of culture and then expend effort on defining culture - a term that is remarkably resistant to being pinned down. Second, we could claim that cultural history is what those who call themselves cultural historians do: culture is not, according to this approach, defined so much as allowed to emerge through scholarly practices. Third, it may be worth thinking about the areas of history that cultural history stands in implied comparison or explicit opposition to, in which case it is largely negatively defined. Whatever approach is taken, however, cultural history privileges the capacity of human beings to generate ideas, ways of life, meanings, objects, images and sounds, texts and so on. Yet these terms immediately show one of the problems with trying to tie down cultural history - there are innumerable fields that specialize in such areas-film studies, history of dress and musicology, for instance. Many of them are not, at least in Britain, normally represented in departments of history. Hence a great deal of cultural history goes on outside history as a discipline, and is particularly prominent in departments that focus on the study of literature.

There is another way of thinking about the current state and recent history of cultural history in Britain, which is a version of the second approach I just mentioned. This took self-definition as the major criterion, and a similar criterion could be applied to institutions, organisations, degree schemes and so on, that call themselves and define their own identity in terms of cultural history. A major British example, the cultural history degree at Aberdeen, is discussed elsewhere. While it is hard to generalize given the large number of Universities and Colleges in Britain with their diverse disciplinary structures, I would say that cultural history is remarkably uninstitutionalised in formal, structured ways. There is a Social History Society, but no organization dedicated to cultural history. Nor, so far as I know, are there any dedicated funding streams for the field. There is no British journal that is concerned exclusively with cultural history; 
although the word culture or cultural appears in quite a few journal titles, these are mostly interdisciplinary periodicals.

In Britain, if you are searching for work in cultural history, you might well find it in a geography or area studies journal, in publications that emanate from English literature or from period-specific situations-medieval studies, eighteenth-century studies and so on. Yet I would say that most undergraduates in history departments have a sense that there exists a field called cultural history, they generally know whether it appeals to them or not, and they can recognize examples of it that are put before them. All this suggests that cultural history in Britain is characterized more informally, even intuitively, than formally and organizationally.

At this point we might turn to my third approach. If there are few formal ways in which cultural history is presented, developed and reinforced, then perhaps the grasp of what it is comes from a contrast with other types of historical practice. Built into this contrast, has been, I think, a feeling that cultural history is innovative, even though many of those who wrote historical works, in, for example, the eighteenth century, were, precisely, writing cultural history. Students, then, sense differences between economic, political, diplomatic, demographic and social history on the one hand, and cultural history on the other. But they, like us, might be hard pressed to give a positive and precise account of its defining features. So, by default, defining cultural history becomes an exercise in contrasting it with other kinds of historical activity. It is probably easiest to make a contrast between cultural and political history. The latter has enjoyed a dominant position for a long time in Britain, and there are those who would argue that it still does. There is a stereotype of political history, that it is concerned with elites, government, and the formal exercise of power, according to which it privileges those at the top, especially men, and neglects those at the bottom of society, especially women. But there is actually nothing in the concepts state, politics, authority or government, for example, that is antithetical to culture or cultural history. The recent interest in political culture, particularly evident in work on the French Revolution, makes point neatly.

\section{Social/Cultural}

In Britain arguably the most interesting and complex example of definition by contrast is the relationship between social and cultural history. In one sense cultural history appears more innovative and conceptually sophisticated by comparison with social history. But to make matters more difficult, in another sense, 
cultural history can be presented as a natural outgrowth of social history. The impact of anthropology is an obvious theme in any discussions of the nature of cultural history in the last quarter of the twentieth century. Social history has been more shaped by other social sciences, such as sociology, political economy and economics. By and large the level of engagement with anthropology on the part of cultural historians has been relatively superficial and has consisted more in reading than in direct collaboration. Furthermore, one particular individual, the late Clifford Geertz, seems to have exercised a disproportionate amount of influence, through it should be said, a limited number of articles and essays. Practitioners who have been trained and seriously combine the two, such as Alan McFarlane, are rare. Macfarlane, in addition to his anthropological work, has written about social, local and demographic history as well as about witchcraft, a topic that is both manifestly cultural and well suited to anthropological treatment. Perhaps, the key term here is belief-fundamental for anthropology as it was practiced until recently, necessarily central to culture, and capable of referring to intellectual, emotional and spiritual commitments in a non-judgemental manner. Keith Thomas, whose Religion and the Decline of Magic: Studies in Popular Beliefs in Sixteenth and Seventeenth Century England was published in 1971, would at that time, I suspect, have considered himself to belong to the social rather than the cultural variety of history, although his work has always been concerned with what most people would call cultural history. A good example, his early pioneering article on the double standard, examines beliefs and assumptions as these are translated into social, political and economic practices.

My point is twofold. First, in the 1970s social historians were proclaiming the importance of the social, which included phenomena that could just as well be called cultural. Hence my claim, which I will elaborate, if briefly, in due course, that, in the British context, the relationships between social and cultural history are especially significant. Second, in so far as there was a social science that inspired this wide-ranging form of social history, it was more anthropology than sociology or any other social science. Historical sociology is a distinct field of sociology not of history and continues to be practised-strictly speaking there is no equivalent term for a field of history, social history is as close as it gets. There were members of the British academic community at that time, who were thinking about the relationships between sociology and history and Gareth Stedman Jones, is a good example. His writings have always been concerned with categories of thought as well as with social practices, yet I suspect he would not describe himself as a cultural historian. There were, I believe, some good reasons why anthropology appealed to historians far more than sociology. Put crudely, it was because anthropology was thought to legitimate belief systems 
other than, even alien to our own, and to offer ways of studying them as cultural systems that possessed integrity in their own right. Thus anthropology could be equally inspirational for the study of, say, popular protest that involved types of behaviour-dressing up and other forms of disguise - that at first sight seem bizarre to modern eyes, and to historians of magic, witchcraft, and astrology domains about which most $20^{\text {th }}$ century historians were deeply sceptical. Note it was cultural and social anthropology not physical anthropology that appealed to historians then. Other social sciences seemed to offer less immediate and attractive ways forward, even when, within history, the emphasis was on social phenomena so broadly defined as to include cultural ones. Anthropology was, by virtue of its subject matter, perceived as especially alluring, and that is itself a cultural judgement. My comments suggest a peculiar intimacy between the social and the cultural in the British context.

The post-war interest in the social was itself an oppositional move-it sought to topple political history from its perch at the top of the historical tree, and to do so for political reasons, although of course these two uses of the word political are quite distinct. Many on the left felt that high politics, the doings of elites, states and governments, neglected the experiences, voices and struggles of the majority, which deserved, even demanded attention. In opposing and attempting to displace what seemed like an old fashioned, and hierarchical form of history, they were trying to shift the power and authority within the profession to other kinds of scholarly activity. At that moment, which I locate in Britain in the 1960s and 1970s, it would hardly have been appropriate to call this new kind of exploration of the past, cultural history, since there is always an anxiety in Britain, that culture is posh-like the Royal Opera House, Covent Garden - and hence also insensitive to plebeian life. Culture and class are mutually implicated. Yet the culture of plebeian life is itself a major research field, inspired between the 1960s and 1990s by the remarkable work of E.P. Thompson and others.

In practice, it was precisely the culture, as well as the social and economic conditions of life of the masses that was actually being explored. Thompson's Whigs and Hunters of 1977 neatly makes the point. We should note, furthermore, that in the 1970s, social and economic history were still tightly linked. Now their relationship is fragile, economic history is a much smaller field than it was four decades ago, and a number of economic historians practise in departments of economics. In those heady times when two major journals, Social History (1976) and History Workshop Journal (1976) were founded, labour history was an important field, whereas now, at least in Britain, it seems to me to be distinctly marginal. Yet economic history and labour history can both be pursued with cultural matters at their heart and I believe that cultural historians should be 
concerned to support and defend them too. Given our concern with social and cultural hierarchies, there is still a feeling in the UK that art history, for example, out of which some of the most important and distinguished cultural history is currently coming, is a subject that has little to offer historians - the concern about elitism applies. And it applies, interestingly enough, both to the practitioners and the objects of study. Art history has attracted many students from privileged backgrounds and to some extent continues to do so. Art works themselves can be stereotypically presented as divorced from quotidian concerns and hence unable to speak to them. I am not, of course, endorsing these claims, merely pointing out that even with the recent enchantment with cultural history, there are still suspicions and anxieties about its boundaries, and the frameworks that shape it, as well as about its objects of analysis.

At the same time, there is a genuine sense in which social history spawned the new cultural history. I dislike these claims to novelty, since cultural history has been practised for centuries, and I feel it would be profitable for us now to acknowledge and explore its past and engage with specific examples of it. Recent work on the Enlightenment, for example by Mark Phillips, has been doing just this. Nonetheless, the point remains that, partly for career reasons, cultural history was presented as new, and that social history was a principal, although not exclusive source for the historiographical impulses that, in the English speaking worlds, we associate with figures such as Natalie Zemon Davis, Lynn Hunt, and Joan Scott, all of whom are American historians of France.

\section{A Special Relationship?}

This is the place to acknowledge a feature of British historiography that is inescapable, namely the close alliances and affinities between North American and UK historians. Naturally, these stem, at least in part, from the fact that both write in English, and also from shared philosophical, political and religious traditions, despite the manifest differences between the countries. But the fundamental issue here, surely, is power. History as it practised in the United States is powerful; it exercises its sway over many other parts of the world, and above all in Britain. How might we analyse this sway and compare it with the impact of continental traditions? I suspect that a shared commitment to empiricism plays a part. I suspect too that there are ideological affinities at work, manifest, for example, in the general impact of American feminism upon the United Kingdom in the late 60s and 70s, and specifically in the inspiration that British historians of women and gender found in American history writing in this period. There 
is also a resources question lurking here: resources and prestige are difficult to separate. There is, after all, a lot more money around in the North American academy than there is in Britain, and many prominent historians who were born, educated and trained in the UK now practice there: Simon Schama, John Brewer, Linda Colley, and David Cannadine, for example, all of whom have produced works, which, if in a variety of senses, qualify as cultural history. The conditions of work in the United States are markedly superior to those in the UK, while academics there arguably enjoy more respect and status than their British counterparts.

In that respect, North America is more like Continental Europe, at least to this English person's eyes. I well remember the extensive newspaper coverage in France that followed the death of Fernand Braudel (1902-1985), which seemed to me then, and still seems to me now, utterly unlike anything that could happen in the context in which I live and work. In these senses then, and despite the differences between the two areas, when we speak about cultural history in Great Britain, what is happening in North America is a central consideration, and it is even more central, I suggest, than in other domains of history, such as political history, where we have our own long and independent traditions of scholarship that have been shaped by the British political situation as, for example, a more or less continuous monarchy for centuries, and with a particular kind of parliamentary structure in which landed elites played a dominant role until relatively recently. The Anglo-American alliance may then be one significant respect in which our forms of cultural history differ from those on Continental Europe. I am certainly not saying that this is a good thing, I am only saying that an alliance manifestly exists.

\section{Defining Europe}

I should not have lumped European countries together and used the adjective Continental about them in the previous sentence, not least because it is then unclear how Scandinavia fits in. In areas such as the family and gender history there are considerable affinities between Scandinavia and Britain. This was a holding operation, and also a slightly ironic gesture in the direction of what has been happening in our philosophy departments, where there is now a field called Continental philosophy to distinguish it from English-speaking analytical traditions. Here again is definition by contrast, and in my view of a particularly intellectually questionable kind. So, before I pick up again the thread of the relationships between social and cultural history in Britain, let me say a word 
about the ways in which cultural history has been shaped by forces that are not American. This raises interesting questions about colonial, imperial, subaltern influences as well as continental ones. For example, Anna Green, the author of Cultural History, is working in an Australian context, where there is a strong and vibrant historical community, which has a prominent role in public debate. In colonial and post-colonial contexts, culture, however defined, is central: both these contexts and the ways in which historians are approaching them are helping to shape cultural history, especially in Britain where empire has been so central to national identity.

The wave of so-called new cultural history in Britain definitely increased interest in the Annales school-evident, for example, in Peter Burke's book, The French Historical Revolution of 1990. Burke himself is recognized as one of the most successful and influential of Britain's cultural historians, albeit one who is unusually aware of the richness of European and Latin American historiography, past and present. Yet I find it difficult to think of a single British (cultural) historian who could be called a fully-fledged Annaliste. Two other strands of French historiography are worth mentioning for their impact in Britain: work on mentalités and approaches to books, reading and culture associated with Roger Chartier. L'histoire des mentalités has travelled, naturally enough, through English speaking historians who themselves work on France, and it is striking that in general, historians of France have been exceptionally influential in the UK and North America. For example, Colin Jones, who has published extensively on eighteenth-century France and the Revolutionary period, including on medicine, is the current President of the Royal Historical Society. His work is resolutely cultural, even if it would not itself be described as Annaliste, exploring l'histoire des mentalités or conducted in the manner of Chartier. My point is that many, many historians in Britain would be either aware of or have read directly the writings of Philippe Ariès, to take probably the best known writer on mentalités, even if they do not directly emulate him. Without a doubt he has shaped the ways the history of childhood and the history of death are studied in the UK, sometimes directly and sometimes by historians opposing him. Since he integrated toys and paintings into his work on the discovery of childhood, and all manner of visual and material culture into his work on death, any possible definition of cultural history would include him, even as many British historians are critical of him. Thus, the idea that styles of scholarship are defined by contrast and opposition works within as well as between fields. French cultural approaches are well known in the British Isles, they are in some ways influential, but not principally in the sense of attracting direct followers. A few big names attract a disproportionate amount of attention. 
On the whole, however, intellectual traditions in other European countries, such as Begriffsgeschichte, are little known or appreciated in the UK. Of course there are some exceptions, most notably the virtual obsession with Jürgen Habermas among many of those working on the long eighteenth century. Other influences on British cultural history, such as that of the sociologist Norbert Elias, presumably owe a great deal to residence in the country. The same can be said for the legacy of the Warburg Institute, which moved to London in 1934, although there is a complex argument to be made here about the relationships between the history of ideas/intellectual history and cultural history, since on one reading they necessarily overlap considerably, whilst on another they have become quite distinct scholarly communities.

Cultural historians in Britain, then, are selectively aware of European trends, but languages are a significant barrier in a country where doctoral students, for example, frequently work solely in their native tongue, which would be impossible in many parts of Europe. Those working on other countries engage with their historiographies, but, apart from France, the cultural-historical methods and approaches of European countries are rather little known in the UK. We tend to define Europe as France. Individuals with a global reputation, such as Carlo Ginzburg, are an exception, but reading his books does not constitute engagement with Italian intellectual traditions.

\section{Cultural and Social History}

I want to return to the relationships between social and cultural history, bearing in mind that in practice, social and cultural history are both entwined, and in some circumstances, distinct, mutually defining. In the British case, social history was the innovative and politically engaged historical field of the 1960s and 1970s and it was allied with economic history, and indeed with other social sciences, as well as approaches such as oral history, socialist history, women's history, history from below and so on. It was at this time that the Social History Society was founded (1976), and started publishing the journal called Social History. In 2004, however, the journal was refounded as Cultural and Social History. Later issues of the new journal carry a statement at the front:

"Recent epistemological challenges have shaken the core assumptions of many historians. 'Culture' is now seen as a product of social practice, and therefore at the heart of society itself. Cultural and Social History, the official peer-reviewed journal of the Social History Society (SHS), aims to ad- 
dress disciplinary shifts between social and cultural historians. The journal emphasizes the ways the 'social' and 'culture' are inextricable and enable a deeper understanding of each other."

There is no evidence I can discern that the contents of the journal have altered markedly following the change of name. Perhaps what this change signals then, is less a shift in the content or manner of historical activity and more a recognition of the need to be seen to be open to the outcomes of recent epistemological challenges. This phrase is perhaps shorthand for what is sometimes presented as the impact of post-modernism, critical theory and theoretical perspectives in general. Hence, in this context, cultural history stands less for specific subject matter than for a particular orientation towards the practice of history. The second sentence also invites comment. Now? Surely the whole tenor of anthropology is precisely that culture is a product of social practice, and hence its impact, which dates back to the 1960s at least, was already leading historians in just this direction when the Social History Society was initially founded. Thus what has changed, I am suggesting, is less a novel interest in culture as such, than a recognition that cultural history stands more securely for an array of values, such as epistemological sophistication, than social history does. What stems from this recognition is exactly a wish, on the part of at least some sections of the historical community, to be identified with these values, for which cultural history stands as a summary, a tag, a convenient shorthand. Social history was a highly diverse field with respect to values and epistemological sophistication, which reinforces the sense that cultural primarily has rhetorical charge.

This is not to assert that cultural history is an empty phrase; it is merely to recognize that it has a range of meanings and that it is persuasive in a historically specific way. One of the things it is used to signal, for example, is using a wider range of sources, including visual and material, and less frequently, musical ones. Another is a desire to work in more explicitly conceptualized way. A further one may be the expression of a kinship with other disciplines. A great deal of what passes for interdisciplinary history is also, I would say, cultural history. There is indeed an enormous amount of cultural history going on in Britain at the moment, some of it in history departments, but much of it in English, French, geography and so on: it is manifestly interdisciplinary. There is some crossfertilisation and shared endeavour, but nothing consistent. What Britain lacks, by contrast, is formally institutionalised cultural history. It also lacks some specific traditions that have been important elsewhere, such as folklore studies. I cannot account for this situation, only report it. One implication of what I have described is that it is virtually impossible to gage what "questions and topics are 
particularly in demand or have already been dealt with to a large extent." When it comes to the future, what will happen is anyone's guess.

Cultural studies in Britain tends to occupy a place in our academic life that is rather far removed from history, as is evident from the work of Stuart Hall. This is not just because it is more concerned with contemporary phenomena, after all, contemporary history is a field that is flourishing at the moment. Rather the distance is about types of training on the one hand and of theoretical frameworks on the other. I see cultural history within history departments as integrated, and hence enjoying close links with, indeed being simply an accepted part of present-day practice, without particularly needing banners proclaiming itself as a distinct field. What I also see, however, is that mainstream history has not really come to terms with theory - central to cultural studies - and that it has little to do with the social sciences. On my account, then, cultural history-which is strikingly polymorphous - is well placed in Britain, without being especially delineated as a distinct form of history. I am not sure that it would benefit from being more clearly defined and set apart from other forms of history, although I do think that historians would benefit from the discipline as a whole being considerably more active in building alliances with other fields which practise, in some sense, cultural history: my own particular interest is in the potential of art history to productively inform historical practice.

I certainly see myself as a cultural historian, although that is not the only label I would use. Sometimes I would call myself an art historian, a historian of science and/or medicine, a historian of gender or simply state that I am a historian. I also do work that comes under the category of medical humanities, a discipline that does have a certain institutional profile largely because of funding from the Wellcome Trust, but which nonetheless remains under-determined in terms of approaches, framework and content. In one sense medical humanities is all about culture, and includes cultural history/history of medicine within its remit, so perhaps that is a further potential disciplinary identity that I could use. In any individual's life, there are strategic and emotional decisions to be made about which labels to adopt, which journals to publish in, organisations to join, jobs to apply for, and the fact that I have such a choice tells us a lot about the kinds of fragmentation that exist within and around the discipline of history. I have suggested that the phenomenon of fragmentation reveals processes of professionalization and institutionalization, political and economic forces as well as what, for want of a better word, we could call fashion. One way of understanding how all this works is experientially, so I now provide a different kind of account of cultural history in Britain - an autobiographical one. 


\section{An Experiential Account}

I was born in 1949, and took history at school only up to the age of 16 . The history we learned was predominantly political, with a little social and economic. And it was British. I came back to history as a second-year science undergraduate, in 1969, when I took a course in history and philosophy of science. In that context, ideas, discoveries and theories occupied the centre stage, and the contexts in which science was conducted, still less used and disseminated, hardly explored at all. That changed to a degree when I specialized in the subject in my third year and was taught by the late Roy Porter. At that point, I think he would have described himself as a social historian, although he has come to be associated with cultural history. The third-year work was more contextual, but I picked up any historical knowledge I needed, for example, of the French revolution, piecemeal and not systematically as an undergraduate studying history would.

By the time I got my first degree in 1971, I had encountered work on magic and science, had some grasp of the importance of astrology, knew about writers such as Frances Yates, Arthur Lovejoy and Marjorie Hope Nicolson. In other words I had been trained in many of the key areas of cultural history, including the history of knowledge, without the label. When I started doctoral research in the same year, the very first departmental seminar was given by the anthropologist Mary Douglas, whose impact upon both historians and philosophers of science was vast. In that world, historians and philosophers worked together, if not always harmoniously, and questions about concepts and ways of understanding mental operations were fundamental. Furthermore we were concerned with what was then called, science and society. All of these features can, in retrospect, be seen as contributing to what would come to be called the new cultural history, including an interest in the nature and conditions of knowledge. Hence Michel Foucault was widely read by historians and philosophers of science well before he became so fashionable in literature, cultural studies and so on. Further trends, such as science and literature, reinforced what I suppose we could call a cultural turn.

I observe, first, that these cultural approaches were and are significantly interdisciplinary, and second, that they did not necessarily appear as a zone deliberately labeled cultural history. By the time I left Cambridge in 1978 having done a doctorate and held a research fellowship for three years and taught in history, social and political science and education as well as history and philosophy of science, and researched wax anatomical models and opera as well as a range of written sources, I guess I was doing a kind of cultural history that I have been more deliberately developing ever since, including by taking a de- 
gree in art history. For me this was about developing a path that felt right rather than consciously reflecting upon cultural history as a category. This changed however when, early in 1993, I was invited to apply for a post at York that was explicitly designed to develop further cultural history there - they already had a small one-year master's programme. I spent my three years there reflecting and helping to organize events on cultural history, but am not sure that we came to any new conclusions about it.

My next job was in a department of world art studies and museology, followed by a post running an interdisciplinary research centre. I currently teach in a history department, where there are many cultural historians, especially among the early modernists. Nonetheless the primary classification within the department is by period rather than historiographical style. One of my colleagues, the distinguished cultural historian Anne Goldgar, teaches courses that make explicit that they are cultural history-for example, Themes in Early Modern Cultural History, a second-year undergraduate option-while the rest of us deploy ideas and approaches that can be read that way. For example, I have taught an MA module called "The Construction of Modern Heroism, 1725-1930". The word "construction" clearly signals a particular historiographical orientation, that could be described as cultural, while the dates signal an interest in longue durée phenomena, which could be described as mentalités. Yet I do not especially present the course either publicly or in my head as cultural history. I cannot see that anything in particular would be gained by it, yet, as I have shown, my entire approach to my work has been shaped by thinking about culture and how to study such a protean and elusive concept, and by a seminal figure I have not so far mentioned, Raymond Williams, whose Keywords: A Vocabulary of Culture and Society (1976) as well as his books such as The Country and the City (1973) have been major influences, as have art-history scholars, such as Michael Baxandall and Marcia Pointon.

So one question that arises from my account is when and where has it been advantageous or necessary to signal the presence of cultural history? I have suggested that, given the array of approaches and disciplines that are currently practising what is on any definition recognizable as cultural history, there can be no simple answer. At the same time, I can see that for marketing purposes, for example, clear boundaries and signals can be helpful. At the level of research, however, surely it is vital simply to be flexible and open.

I shall conclude, however, on two rather different notes. In his 1983 book on Gender, Ivan Illich memorably says that this phenomenon is more about what occurs between the ears than between the legs. I appreciate this thought; perhaps cultural history is the activity that places what happens between the ears at cen- 
tre stage, and develops its practices and principal analytical modes accordingly. Some might say that the concept of representation would play a leading role, but I suggest that mediation is even more important. Cultural history conceptualizes, examines and gives priority to mediations. My second thought is that if this is correct, then all history must be cultural history, since our discipline, like others, such as art history and literature, gives priority to human doings, which always entail mental operations of some kind. However, the ways in which historians practise is shaped by many forces. Even if we have the centrality of mediation in common across Europe, we still have our socially constructed baggage. It is difficult to identify the national elements among the rich mix of preconceptions, assumptions, generational effects, political and religious commitments and individual idiosyncracies that shape the ways in which communities of historians view the past. In so far as it is possible to generalize, cultural history in Britain is thriving, and perhaps there is something significant in the fact that it does so in a rather higgledy-piggledy fashion.

\section{Literature}

ARIES, PhILlIPPE, Centuries of Childhood: a Social History of Family Life, New York 1962 (first published in French in 1960).

ID., The Hour of Our Death, New York 1981 (first published in French in 1977). BARRell, John, The Dark Side of the Landscape: the Rural Poor in English Painting, Cambridge 1980.

Baxandall, Michael, Painting and Experience in Fifteenth Century Italy: A Primer in the Social History of Pictorial Style, Oxford 1972.

ID., Patterns of Intention: on the Historical Explanation of Pictures, New Haven 1985.

BREWER, JoHN, The Pleasures of the Imagination: English Culture in the Eighteenth Century, London, 1997.

Burke, Peter, The French Historical Revolution: the Annales School, 1929-89, Cambridge 1990.

CAnnadine, David, Ornamentalism: how the British saw their Empire, London 2001.

Chartier, Roger, The Cultural Uses of Print in Early Modern France, Princeton 1987.

Colley, Linda, BRITONs: Forging the Nation, 1707-1837, New Haven 1992.

Davis, Natalie Zemon, Society and Culture in Early Modern France: Eight Essays, London, 1975. 
Douglas, MARY, Purity and Danger: an Analysis of Concepts of Pollution and Taboo, London 1966.

Elias, NoRbert, The Civilizing Process: The History of Manners, Vol. 1, Oxford 1978 (first published in German in 1968).

Foucault, Michel, The Archaeology of Knowledge, London 1972 (first published in French in 1969).

ID., The Birth of the Clinic: an Archaeology of Medical Perception, London 1973 (first published in French in 1963).

GEERTZ, CLIFFORD, The Interpretation of Cultures: Selected Essays, New York 1973.

GinZburg, CARLo, The Cheese and the Worms: the Cosmos of a Sixteenth-century Miller, London 1980 (first published in Italian in 1976).

GoldGar, AnNe, Tulipmania: Money, Honor, and Knowledge in the Dutch Golden Age, Chicago and London, 2007.

GreEn, ANNA, Cultural History, Basingstoke 2008.

Habermas, JÜRgEn, The Structural Transformation of the Public Sphere: an Inquiry into a Category of Bourgeois Society, Cambridge, 1989 (first published in German in 1962).

Hall, Stuart, Television as a Medium and its Relation to Culture, Birmingham 1975.

Hunt, LynN, Politics, Culture, and Class in the French Revolution, Berkeley/ London 1984.

ILLICH, IVAN, Gender, London 1983.

Jones, Colin, Madame de Pompadour: Images of a Mistress, London 2002.

LOVEJoY, ARTHUR, The Great Chain of Being: a Study of the History of an Idea, Cambridge, Mass. 1936.

Macfarlane, Alan, The Family Life of Ralph Josselin, a Seventeenth-Century Clergyman; an Essay in Historical Anthropology, Cambridge 1970.

ID., Witchcraft in Tudor and Stuart England: a Regional and Comparative Study, London 1970.

ID., Marriage and Love in England: Modes of Reproduction, Oxford 1986.

NicOlson, MARJORIE HoPE, Mountain Gloom and Mountain Glory: the development of the Aesthetics of the Infinite, Ithaca, N.Y. 1959.

PhILlIPS, MARK, Society and Sentiment: Genres of Historical Writing in Britain, 1740-1820, Princeton, N.J. 2000.

Pointon, Marcia, Hanging the Head: Portraiture and Social Formation in Eighteenth-century England, New Haven/London 1993.

PORTER, ROY, English Society in the Eighteenth Century, Harmondsworth 1982. Schama, Simon, Citizens: A Chronicle of the French Revolution, London 1989. 
SCOTT, JoAn, Gender and the Politics of History, New York 1988.

Skinner, Quentin, The Foundations of Modern Political Thought, Cambridge 1978 (2 volumes).

Stedman Jones, Gareth, From Historical Sociology to Theoretical History, in: British Journal of Sociology 27 (1976), p. 295-305.

Thomas, KeIth, The Double Standard, in: Journal of the History of Ideas 20 (1959), p. 195-216.

ID., Religion and the Decline of Magic: Studies in Popular Beliefs in Sixteenth and Seventeenth Century England, London 1971.

Thompson, E.P., The Making of the English Working Class, London 1963.

ID., Whigs and Hunters: the Origin of the Black Act, London 1975.

ID., Customs in Common, London 1991.

WiLliams, RAYMOND, Keywords: A Vocabulary of Culture and Society, London 1976 (a revised edition appeared in 1983).

YATES, FranCES, The Art of Memory, London 1966.

ID., The Rosicrucian Enlightenment, London 1972. 